\title{
Novel PCR Assay for Determining the Genetic Sex of Mice
}

\author{
L. McFarlane V.Truong J.S. Palmer D. Wilhelm
}

Division of Molecular Genetics and Development, Institute for Molecular Bioscience, The University of Queensland, Brisbane, Qld., Australia

\section{Key Words}

Genetic sex $\cdot$ Mouse $\cdot$ PCR $\cdot$ Sex determination .

$X$ chromosome $\cdot Y$ chromosome

\begin{abstract}
A number of studies require the determination of the genetic sex of mouse embryos before sexual differentiation and/or of mutant mice that display partial or complete sex reversal. The majority of current methods for sexing by $P C R$ involve multiplexing of 2 primer pairs. We have developed a novel sexing PCR using a single primer pair that amplifies fragments from the $X$ and the $Y$ chromosome with a clear size difference between the respective amplicons. This assay provides a rapid and reliable method to identify the genetic sex of mice across different mouse strains.
\end{abstract}

Copyright $\odot 2013$ S. Karger AG, Basel

In mice, like in most mammals, genetic sex is determined at the time of fertilization when the $\mathrm{X}$ chromosome-bearing oocyte receives an $\mathrm{X}$ or a $\mathrm{Y}$ chromosome from the sperm. XX and XY individuals will normally develop into females and males, respectively. Sexual differentiation, however, does not start until approximately 11.5 days post coitum, when the male-determining gene Sry is expressed from the $\mathrm{Y}$ chromosome in the bipotential genital ridge, the embryonic anlage of the gonads. The expression of Sry induces a complex network of testis-spe- cific gene expression, regulation and interaction that directs the differentiation of the genital ridge into a testis. If no functional Sry is expressed, or its expression is delayed, female-determining gene pathways are activated resulting in the development of an ovary [Wilhelm et al., 2007]. The testes and ovaries then produce hormones that will drive the differentiation of most, if not all, other secondary sexual characteristics. Until these differentiation processes take place, XX and XY embryos are morphologically and anatomically indistinguishable. Any experiments utilising samples before such a stage require sexing by other means.

Methods to determine the genetic sex are also necessary to study mice with partial or complete sex reversal. These mutations have been found in a number of genes involved in sex determination and sex differentiation. They encode factors expressed in the bipotential genital ridge prior to Sry expression such as the insulin receptors [Nef et al., 2003], primary sex determining genes like Sox9 in XY and Ctnnb1 in XX animals [Chaboissier et al., 2004; Barrionuevo et al., 2006; Liu et al., 2009] as well as downstream genes such as Fgf9 and its receptor Fgfr2 [Schmahl et al., 2004; Kim et al., 2007; Bagheri-Fam et al., 2008]. Similarly, transgenic mice with ectopic gene expression in the developing gonads display sex reversal phenotypes such as the expression of Sox 3 or Sox 10 in an ovary resulting in XX female-to-male sex reversal [Polanco et al., 2010; Sutton et al., 2011]. In order to fully characterize the phenotypes of these mice, it is critical to unequivocally determine their genetic sex.

\section{KARGER}

E-Mail karger@karger.com

www.karger.com/sxd
(C) 2013 S. Karger AG, Basel

1661-5425/13/0074-0207\$38.00/0
Dagmar Wilhelm

Department of Anatomy and Developmental Biology

Monash University

Clayton, VIC 3168 (Australia)

E-Mail dagmar.wilhelm@monash.edu 
Over the years, a variety of methods have been developed to identify the genetic sex of mouse embryos. These range from enzyme assays detecting the activity of the $\mathrm{X}$-linked enzyme glucose-6-phosphate dehydrogenase [Williams, 1986] to cytogenetic techniques such as chromosome C-banding [Gimenez et al., 1993] or amnion staining to visualize the Barr body [Capel and Batchvarov, 2008], which are of limited use because they require experience or have low accuracy. More recently, PCR amplification of Y-chromosomal DNA that detects the maledetermining gene Sry [Kunieda et al., 1992; Greenlee et al., 1998; Lavrovsky et al., 1998; Lambert et al., 2000; McClive and Sinclair, 2001] and/or the Y-chromosomal gene Zfy [Kunieda et al., 1992; Greenlee et al., 1998; Beverdam et al., 2010] has been used to determine male genetic sex. However, in these assays, female genetic sex is concluded based on the absence of a PCR amplicon. To overcome this limitation, several PCR assays have been developed that combine detection of Sry and/or Zfy with the amplification of an X-chromosomal gene or an autosomal gene as internal control. Examples of these internal controls include Dxnds3 [Kunieda et al., 1992; Greenlee et al., 1998], the genes encoding the $\beta$-subunit of the thyroidstimulating hormone (TSH $\beta)$ [Lavrovsky et al., 1998], myogenin (Myog) [McClive and Sinclair, 2001], and interleukin 3 (Il3) [Lambert et al., 2000]. Owing to the potential confounding problems with multiplex PCR assays [Markoulatos et al., 2002], the development of a simplex PCR assay for determining genetic sex is an important goal.

There are currently only 2 methods described that use a simplex PCR assay for the determination of the genetic sex in mice [Chuma and Nakatsuji, 2001; Clapcote and Roder, 2005]. The first of these uses PCR to amplify the homologous genes Uba1 and Ube1y1 on the X and $\mathrm{Y}$ chromosome, respectively. Here, the primers were designed to cover deleted regions within the Ube1y1 gene, resulting in 2 amplification products in males, but only the larger product in females [Chuma and Nakatsuji, 2001]. The alternative simplex method uses a single set of primers to amplify the X-chromosomal gene $K d m 5 c$ (formerly Jarid1c) and the Y-chromosomal gene $K d m 5 d$ (formerly Jarid1d; [Clapcote and Roder, 2005]). However, in both cases, the size differences of the amplicons are relatively small, 19 bp for Uba1/Ube1y1 and 29 bp for $K d m 5 c / d$, presenting some difficulties in accurately assessing the results by gel electrophoresis. Here, we present a novel PCR assay using 1 pair of primers that results in a much larger size difference for products generated from the $\mathrm{X}$ and the $\mathrm{Y}$ chromosome, respectively.

\section{Materials and Methods}

\section{Mouse Strains}

Tail tissue was collected from the outbred CD1 and Quackenbush, the inbred C57BL/6, Balb/c, FVB, and 129 mouse strains as well as from mice on a mixed background $(\mathrm{CBA} \times \mathrm{C} 57 \mathrm{BL} / 6)$. Protocols and use of animals were approved by the Animal Welfare Unit of the University of Queensland (approval \# IMB/131/09/ $\mathrm{ARC}$ ), which is registered as an institution that uses animals for scientific purposes under the Queensland Animal Care and Protection Act (2001).

\section{DNA Extraction}

Pieces of mouse tissue were placed in $200 \mu \mathrm{l}$ of PBND buffer (PCR buffer with non-ionic detergents, $50 \mathrm{mM} \mathrm{KCl,} 10 \mathrm{mM}$ Tris$\mathrm{HCl} \mathrm{pH} \mathrm{8.3,} 2.5 \mathrm{mM} \mathrm{MgCl}_{2}, 0.1 \mathrm{mg} / \mathrm{ml}$ gelatin, $0.45 \%$ (v/v) Nonidet P-40, $0.45 \%(\mathrm{v} / \mathrm{v})$ Tween 20; autoclaved and stored frozen) supplemented with $100 \mu \mathrm{g} / \mathrm{ml}$ proteinase K. Samples were incubated at $55^{\circ} \mathrm{C}$ with occasional vortexing for $15 \mathrm{~min}$ up to overnight, followed by heat-inactivation of the proteinase $\mathrm{K}$ at $95^{\circ} \mathrm{C}$ for $5 \mathrm{~min}$. One microliter of each sample was added directly to a $25 \mu \mathrm{l} \mathrm{PCR}$ reaction.

\section{Primer Design}

Genomic sequences for the X-chromosomal Xlr (X-linked lymphocyte-regulated complex, NM_011725) and the Y-chromosomal Sly (Sycp3-like Y-linked, BC049626) genes were obtained from the UCSC server [Kent et al., 2002] and compared for sequence identity using BLASTN (v2.2.23) [Altschul et al., 1997]. Genomic regions with high sequence identity were re-aligned using the CLUSTAL X Multiple Sequence Alignment Program (v2.0.12) (http://www.clustal.org) and analysed using the Jalview (v2.6) sequence alignment editor [Clamp et al., 2004]. Candidate primer pairs were analysed using NetPrimer (http://www.premierbiosoft. com/netprimer/index.html) and screened for specificity using NCBI Primer-BLAST [Ye et al., 2012] and UCSC in silico PCR [Zweig et al., 2008].

\section{PCR Reactions}

Genomic DNA was amplified with the following primer pairs: SX_F， 5'-GATGATTTGAGTGGAAATGTGAGGTA-3'; SX_R, 5'-CTTATGTTTATAGGCATGCACCATGTA-3'; Zfy_F, 5'-GACTAGACATGTCTTAACATCTGTCC-3'; Zfy_R, 5'-CCTATTGCATGGACTGCAGCTTATG-3' [Beverdam et al., 2010]; Ube_F, 5'-TGGTCTGGACCCAAACGCTGTCCACA-3'; Ube_R, 5'-GGCAGCAGCCATCACATAATCCAGATG-3' [Chuma and Nakatsuji, 2001]. PCR reactions were performed in a final volume of 25 $\mu \mathrm{l}$ with $10 \mathrm{~mm}$ Tris- $\mathrm{HCl} \mathrm{pH} 8.3,50 \mathrm{mM} \mathrm{KCl}, 1.5 \mathrm{mM} \mathrm{MgCl}_{2}, 0.2$ mM dNTPs, $0.2 \mu \mathrm{M}$ primers, and 1 unit Taq polymerase (New England Biolabs, Mass., USA) and the following PCR parameters: initial denaturation at $94^{\circ} \mathrm{C}$ for $2 \mathrm{~min}, 35$ cycles with $94^{\circ} \mathrm{C}$ for $30 \mathrm{~s}$, $57^{\circ} \mathrm{C}$ (SX and Ube primers) and $55^{\circ} \mathrm{C}$ (Zfy primers) for $30 \mathrm{~s}$, and $72^{\circ} \mathrm{C}$ for $30 \mathrm{~s}$, followed by final elongation at $72^{\circ} \mathrm{C}$ for $5 \mathrm{~min}$. PCR products were electrophoresed together with a DNA ladder (100 bp, New England Biolabs) on 2\% agarose gels and visualized with ethidium bromide under UV-illumination. 


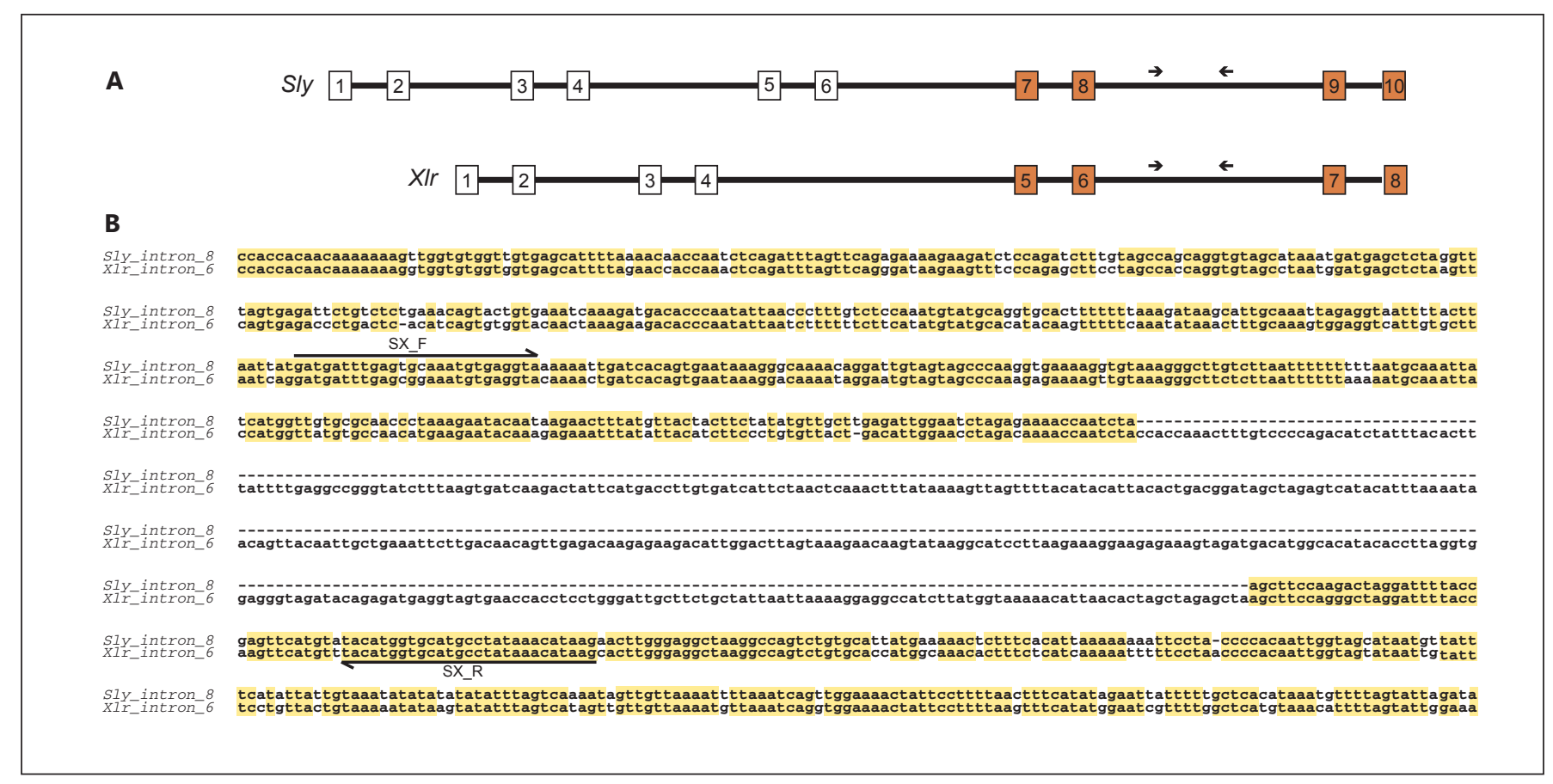

Fig. 1. Comparison of the pseudoautosomal genes Sly and Xlr. A Schematic representation (not to scale) of the genomic arrangements of Sly and Xlr. Homologous exons are marked in orange. Primers are indicated with arrows. B Sequence alignment of Sly intron 8 and $X l r$ intron 6 . The alignment of the homologous in- trons of the Y-chromosomal gene Sly (intron 8) and the X-chromosomal gene $\mathrm{Xlr}$ (intron 6) revealed a 405-bp deletion in Sly intron 8. Primers to amplify these regions from the sex chromosomes are indicated with forward (SX_F) and reverse (SX_R) arrows. Identical regions between the 2 genes are marked by yellow boxes.

\section{Results and Discussion}

To identify suitable genes for the determination of the genetic sex of mouse embryos, we selected the pseudoautosomal genes Xlr and Sly. These genes belong to highly multicopy gene families with homologues on the $\mathrm{X}$ and $\mathrm{Y}$ chromosomes. The Y-chromosomal Sly gene family consists of at least 70 copies with additional 30 noncoding copies identified [Toure et al., 2005; Cocquet et al., 2009]. The encoded protein is specifically expressed in round spermatids and is thought to play a role in postmeiotic sex chromosome repression [Cocquet et al., 2009]. In contrast, the Xlr gene family encodes RNA transcripts that are stage-specifically expressed in lymphoid cells, predominantly late-stage T and B cells [Cohen et al., 1985; Siegel et al., 1987]. Like Sly, the Xlr gene family consists of numerous copies, with estimates of 50-70 copies per haploid genome, localized in at least 2 different areas of the mouse X chromosome [Garchon et al., 1989]. To date, only 1 potential protein-coding transcript has been identified, with all others predicted to be noncoding [Siegel et al., 1987; Garchon et al., 1989].

Sex Genotyping by PCR
Interestingly, Sly arose as a chimeric gene fusion of the $\mathrm{X}$-linked genes Xmr (also known as $S l x$ ) and Xlr. Sly exons 1-4 are derived from $\mathrm{Xmr}$ exons 1-4, followed by a duplication of Xmr exons 3-4. The 3'-end of Sly, exons 7-10, matches $\mathrm{Xlr}$ exons 5-8 (fig. 1A) [Ellis et al., 2007]. The alignment of the homologous regions of Sly (exon 7-10) and Xlr (exon 5-8) identified a 405-bp deletion within intron 8 of Sly by comparison to intron 6 of Xlr (fig. 1B). This suggested that PCR amplification across this region should result in amplicons with a large enough size difference to be easily distinguished by gel electrophoresis. We designed primers to regions upstream and downstream of the deletion that were almost identical between the 2 genes (fig. 1, arrows) and would yield a 280-bp and a 685-bp PCR product for Sly and Xlr, respectively.

We next performed PCR in a blinded assay with genomic DNA from $3 \mathrm{XX}$ and $3 \mathrm{XY}$ mice from each of the following mouse strains, CD1 (fig. 2A), C57BL/6 (fig. 2B) and mixed background (CBA $\times$ C57BL6; fig. 2C). Each genomic DNA was used in a PCR reaction with the primers for $S l y / X l r$ as well as primer pairs for $Z f y$ [Beverdam et al., 
Fig. 2. Determination of the sex of mice using Sly/Xlr PCR. XX and XY mouse genomic DNA from CD1 (A), C57BL/6 (B6) (B) and mixed background (C) mice was used as template to amplify Sly intron 8 from the Y chromosome and Xlr intron 6 from the X chromosome (SX, right panels). As controls, the same genomic DNAs were used as template to amplify $Z f y$ (left panels) and Uba1/Ube1y1 (Ube, middle panels). $\mathrm{L}=100$-bp DNA ladder.

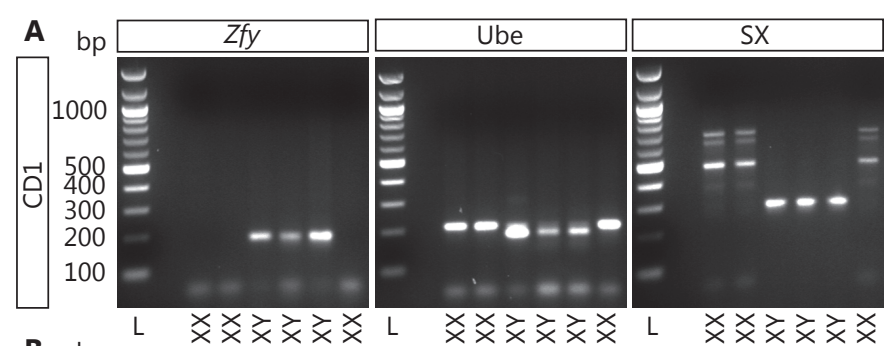

B bp
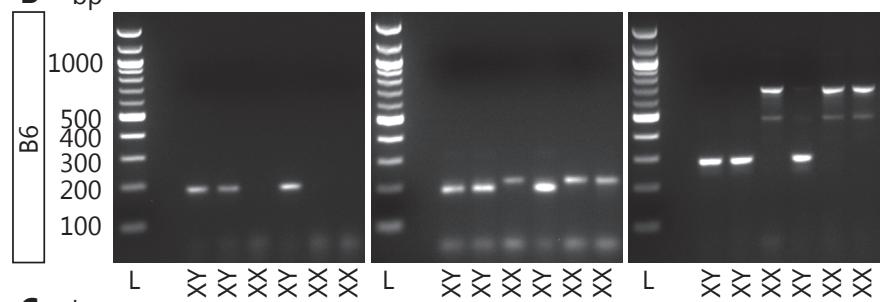

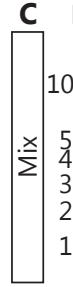

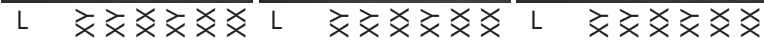

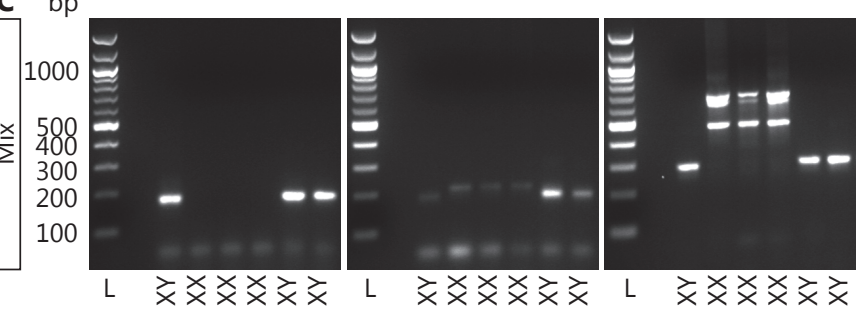

2010] and Uba1/Ube1y1 [Chuma and Nakatsuji, 2001] as controls. Sexing PCR using Zfy primers confirmed the presence of the Y chromosome in 3 out of the 6 samples for each mouse strain (fig. 2, left panels). Similarly, using the primers amplifying Ubal from the X chromosome and Ube1y1 from the Y chromosome, we obtained the expected 217-bp Uba1 in XX samples and the 198-bp Ube1y1, but rarely detected the 217-bp product in $\mathrm{XY}$ samples (fig. 2, middle panels).

As predicted, amplification using the primers for $S l y / X l r$ resulted in a 280 -bp product from the Y chromosome. However, amplification from the $\mathrm{X}$ chromosome not only yielded the expected 685-bp fragments, but also products of approximately 480 and $660 \mathrm{bp}$ (fig. 2, left panels). Similar to the Uba1/Ube1y1 assay, the larger PCR products from the $\mathrm{X}$ chromosome were often only faintly detected using XY genomic DNA. This is most likely due to the preferential amplification of shorter products. Sequencing of some of the X-chromosomal PCR products revealed that they arise from different copies of the $\mathrm{Xlr}$ gene family (data not shown). The same amplification products were obtained for $\mathrm{XX}$ and $\mathrm{XY}$ mice from the in- bred mouse strains 129, Balb/c and FVB as well as for the outbred Quackenbush mice (data not shown), showing that this PCR is a reliable method to identify the genetic sex of mice across different mouse strains.

To determine the optimal annealing temperature for the primer pair, we repeated the PCR using different annealing temperatures ranging from 45 to $65^{\circ} \mathrm{C}$. We obtained the expected PCR products at all temperatures tested with the highest yield for both sexes at $52.7^{\circ} \mathrm{C}$ and $57.6^{\circ} \mathrm{C}$ (data not shown). In addition, we shortened the incubation steps during the PCR for rapid genotyping, which is essential, for example, for experiments involving the culture of live tissues. Sufficient amplification was still achieved with initial denaturation at $94^{\circ} \mathrm{C}$ for $3 \mathrm{~min}$, followed by 35 cycles of $15 \mathrm{~s}$ each of 94,57 and $72^{\circ} \mathrm{C}$, and a final elongation for $5 \mathrm{~min}$ at $72^{\circ} \mathrm{C}$. A further reduction in time was achieved by the short amount of time needed for the gel electrophoreses. Due to the considerable size difference of the amplicons, $15 \mathrm{~min}$ at $100 \mathrm{~V} / \mathrm{cm}$ was sufficient for their separation, making it a fast and reliable method to determine the genetic sex of mice and mouse embryos. 
Our new sexing PCR method not only has the advantage that it uses a single primer pair to amplify sequences from both the $\mathrm{X}$ and the $\mathrm{Y}$ chromosome simultaneously, but also it is easy to interpret the results based on the large size differences in the fragments obtained from the $\mathrm{X}$ and $\mathrm{Y}$ chromosome, respectively. In addition, our assay is robust, can be used for different mouse strains, saves time and material, and is therefore less expensive than other methods.

\section{Acknowledgements}

We thank Dr. Terje Svingen for critical reading of the manuscript. This work was supported by research grants from the National Health and Medical Research Council of Australia (NHMRC grant No. 631460) and the Australian Research Council (ARC grant No. DP0879913). D.W. is a Future Fellow of the ARC (FT110100327).

\section{References}

Altschul SF, MaddenTL, Schäffer AA, Zhang J, Zhang Z, et al: Gapped BLAST and PSIBLAST: a new generation of protein database search programs. Nucleic Acids Res 25:33893402 (1997).

Bagheri-Fam S, Sim H, Bernard P, Jayakody I, Taketo MM, et al: Loss of Fgfr2 leads to partial XY sex reversal. Dev Biol 314:71-83 (2008).

Barrionuevo F, Bagheri-Fam S, Klattig J, Kist R, Taketo MM, et al: Homozygous inactivation of Sox 9 causes complete XY sex reversal in mice. Biol Reprod 74:195-201 (2006).

Beverdam A, Svingen T, Bagheri-Fam S, McClive P, Sinclair AH, et al: Protein tyrosine kinase 2 beta (PTK2B), but not focal adhesion kinase (FAK), is expressed in a sexually dimorphic pattern in developing mouse gonads. Dev Dyn 239:2735-2741 (2010).

Capel B, Batchvarov J: Sex chromatin staining in amnion cells. CSH Protoc 2008:pdb.prot5079 (2008).

- Chaboissier MC, Kobayashi A, Vidal VI, Lützkendorf S, van de Kant HJ, et al: Functional analysis of Sox8 and Sox9 during sex determination in the mouse. Development 131:18911901 (2004).

Chuma S, Nakatsuji N: Autonomous transition into meiosis of mouse fetal germ cells in vitro and its inhibition by gp130-mediated signaling. Dev Biol 229:468-479 (2001).

Clamp M, Cuff J, Searle SM, Barton GJ: The Jalview Java alignment editor. Bioinformatics 20:426-427 (2004).

-Clapcote SJ, Roder JC: Simplex PCR assay for sex determination in mice. Biotechniques 38:702, 704, 706 (2005).

Cocquet J, Ellis PJ, Yamauchi Y, Mahadevaiah SK, Affara NA, et al: The multicopy gene Sly represses the sex chromosomes in the male mouse germline after meiosis. PLoS Biol 7:e1000244 (2009).

Cohen DI, Steinberg AD, Paul WE, Davis MM: Expression of an X-linked gene family (XLR) in late-stage $\mathrm{B}$ cells and its alteration by the xid mutation. Nature 314:372-374 (1985).

-Ellis PJ, Ferguson L, Clemente EJ, Affara NA: Bidirectional transcription of a novel chimeric gene mapping to mouse chromosome Yq. BMC Evol Biol 7:171 (2007).
Garchon HJ, Loh E, Ho WY, Amar L, Avner P, Davis MM: The XLR sequence family: dispersion on the $\mathrm{X}$ and $\mathrm{Y}$ chromosomes of a large set of closely related sequences, most of which are pseudogenes. Nucl Acids Res 17:98719888 (1989).

Gimenez C, Egozcue J, Vidal F: Cytogenetic sexing of mouse embryos. Hum Reprod 8:470474 (1993).

Greenlee AR, Krisher RL, Plotka ED: Rapid sexing of murine preimplantation embryos using a nested, multiplex polymerase chain reaction (PCR). Mol Reprod Dev 49:261-267 (1998).

Kent WJ, Sugnet CW, Furey TS, Roskin KM, Pringle TH, et al: The human genome browser at UCSC. Genome Res 12:996-1006 (2002).

Kim Y, Bingham N, Sekido R, Parker KL, LovellBadge R, Capel B: Fibroblast growth factor receptor 2 regulates proliferation and Sertoli differentiation during male sex determination. Proc Natl Acad Sci USA 104:1655816563 (2007).

Kunieda T, Xian M, Kobayashi E, Imamichi T, Moriwaki K, Toyoda Y: Sexing of mouse preimplantation embryos by detection of Y chromosome-specific sequences using polymerase chain reaction. Biol Reprod 46:692-697 (1992).

Lambert JF, Benoit BO, Colvin GA, Carlson J, Delville Y, Quesenberry PJ: Quick sex determination of mouse fetuses. J Neurosci Methods 95:127-132 (2000).

Lavrovsky Y, Song CS, Chatterjee B, Roy AK: A rapid and reliable PCR-based assay for gene transmission and sex determination in newborn transgenic mice. Transgenic Res 7:319320 (1998).

Liu CF, Bingham N, Parker K, Yao HH: Sex-specific roles of beta-catenin in mouse gonadal development. Hum Mol Genet 18:405-417 (2009).

Markoulatos P, Siafakas N, Moncany M: Multiplex polymerase chain reaction: a practical approach. J Clin Lab Anal 16:47-51 (2002).
McClive PJ, Sinclair AH: Rapid DNA extraction and PCR-sexing of mouse embryos. Mol Reprod Dev 60:225-226 (2001).

Nef S, Verma-Kurvari S, Merenmies J, Vassalli JD, Efstratiadis A, et al: Testis determination requires insulin receptor family function in mice. Nature 426:291-295 (2003).

Polanco JC, Wilhelm D, Davidson TL, Knight D, Koopman P: Sox10 gain-of-function causes $\mathrm{XX}$ sex reversal in mice: implications for human 22q-linked disorders of sex development. Hum Mol Genet 19:506-516 (2010).

Schmahl J, Kim Y, Colvin JS, Ornitz DM, Capel B: Fgf9 induces proliferation and nuclear localization of FGFR2 in Sertoli precursors during male sex determination. Development 131: 3627-3636 (2004).

-Siegel JN, Turner CA, Klinman DM, Wilkinson $\mathrm{M}$, Steinberg AD, et al: Sequence analysis and expression of an X-linked, lymphocyte-regulated gene family (XLR). J Exp Med 166:17021715 (1987).

Sutton E, Hughes J, White S, Sekido R, Tan J, et al: Identification of SOX3 as an XX male sex reversal gene in mice and humans. J Clin Invest 121:328-341 (2011).

Toure A, Clemente EJ, Ellis P, Mahadevaiah SK, Ojarikre OA, et al: Identification of novel Y chromosome encoded transcripts by testis transcriptome analysis of mice with deletions of the Y chromosome long arm. Genome Biol 6:R102 (2005).

Wilhelm D, Palmer S, Koopman P: Sex determination and gonadal development in mammals. Physiol Rev 87:1-28 (2007).

-Williams TJ: A technique for sexing mouse embryos by a visual colorimetric assay of the X-linked enzyme, glucose 6-phosphate dehydrogenase. Theriogenology 25:733-739 (1986).

-Ye J, Coulouris G, Zaretskaya I, Cutcutache I, Rozen S, Madden TL: Primer-BLAST: a tool to design target-specific primers for polymerase chain reaction. BMC Bioinformatics 13:134 (2012).

Zweig AS, Karolchik D, Kuhn RM, Haussler D, Kent WJ: UCSC genome browser tutorial. Genomics 92:75-84 (2008). 